\title{
Perceptions of Medical Students towards the Use of Internet in the Learning Process of Problem-Based Learning
}

Submitted: $16-10-2018$

Accepted: 23-11-2018

Online: 26-02-2019

\author{
Nilesh Kumar Mitra', Kartigan Ganaeswaren², \\ Paul Patrick Berundang ${ }^{2}$ \\ ${ }^{1}$ School of Medicine, International Medical University, \\ Kuala Lumpur, MALAYSIA \\ ${ }^{2}$ School of Medicine, Taylor's University, Selangor, MALAYSIA
}

To cite this article: Mitra NK, Ganaeswaren K, Berundang PP. Perceptions of medical students towards the use of Internet in the learning process of problem-based learning. Education in Medicine Journal. 2018;10(4):1-7. https://doi.org/10.21315/eimj2018.10.4.1

To link to this article: https://doi.org/10.21315/eimj2018.10.4.1

\begin{abstract}
This study aimed to evaluate the perceptions of medical students towards use of Internet in problembased learning (PBL). A descriptive observational approach was followed in analysis of perceptions about use of Internet in a convenience sample of 141 students. A questionnaire was selected after analysis of perceptions received from a pilot study and was divided into three aspects of the PBL sessions. Students' and facilitators' role in PBL, mode and scope of use of Internet in PBL and reasons for use of Internet in PBL. Descriptive analysis of the data was done. Significant difference between the mean values was analysed. A difference in agreement among the students was observed about the role of facilitators in the process of PBL. A higher percentage of students (65.2\%) agreed that they used Internet to search for information during PBL Session 1 compared to PBL Session 2 $(58.2 \%)$. Majority of the students $(81 \%)$ agreed on searching Internet for new information. Regarding preparation for PBL Session 2, comparatively more students from earlier semesters agreed about using textbooks than using Internet. Higher percentage of students searched Internet for information on clinical sciences (52.5\%) compared to basic sciences (24.8\%). Among basic science subjects, information related to pathology was searched more often and information on management was searched more often among clinical science topics. Students actively use Internet for searching new information and learning during PBL sessions but online search for journal articles is not popular. They also use textbooks to prepare for PBL session.
\end{abstract}

Keywords: Descriptive analysis, Students, Medical, Perception, Internet, Problem-based learning University, Bukit Jalil 57000, Kuala Lumpur, Malaysia | E-mail: NileshKumar@imu. edu.my

\section{INTRODUCTION}

Problem-based learning (PBL) is now a well-established approach used for undergraduate and postgraduate medical education. PBL incorporates active learning instead of the traditional passive lecture-based method (1). It encourages students to seek knowledge on their own and stimulates their minds to think. Many studies have already been done to show the effectiveness of PBL in learning, especially in medical schools $(2,3)$. PBL promotes critical thinking skills, problem- 
solving skills as well as develops student's clinical reasoning process. Development of teamwork and communication skills helps in solving problems in clinical cases (4). Since mid-1990s, educators have started the use of Internet resources for a variety of instructional practices including PBL (5). PBL offers students a disjointed and complex problem that requires research and critical thinking to resolve. Internet being a powerful research tool helps the students in the research towards solving the problem. Although the Internet may contain a lot of information, some of it may be incorrect or outdated and it is desirable that the students should filter the information accordingly. Reliable Internet connectivity and wellresourced libraries facilitate self-directed learning in PBL (6). Review of literature has shown that the scopes of use of Internet in PBL and students' perception towards use of Internet in PBL process have not yet been well explored. Meta-analytical study has reported only subjective change in the learner's behaviour with the use of Internetbased medical education (7). The objective of the study was to evaluate the perceptions of medical students towards the use of Internet in PBL.

\section{METHODS}

\section{Participants}

The study used a descriptive observational approach in analysis of questionnaire-based survey among students of three private medical schools of Malaysia. The students were selected by convenience sampling from Semester 1 to Semester 10 with varying numbers of students in different semesters. The students in the clinical semesters are exposed to either case-based learning or task-based learning, which requires selfstudy using Internet. The survey was done using Google docs in English between June 2016 and July 2016. Consent forms were sent to the students who participated in the survey. The link to the questionnaire was added to the confirmation the students received after submission of the informed consent form. These medical schools use PBL as major educational tool in their preclinical MBBS curricula. Apart from PBL, lectures, practical, clinical skills sessions and hospital visit are also included in the curricula of these medical schools. PBL is included in the student-directed learning hours and helps the students to integrate basic sciences concepts with the problems described in the clinical scenarios. The electronic information resources accessible to the students who participated in the survey are ClinicalKey, a medical search engine and all other free search engines available in any Internet connection. ClinicalKey is subscribed by the library of two out of three universities and accessible to all registered students.

\section{Setting and Data Collection}

The students discuss the key learning issues and the hypotheses of the clinical case given during the first day, usually known as PBL Session 1 and enlist the issues to be presented by them during the second session, usually known as PBL Session 2. The students prepare the contents of the learning issues during the gap between PBL Session 1 and PBL Session 2, and make presentations during the PBL Session 2. In the time table of the module, an interval of three days is usually found between PBL Session 1 and PBL Session 2. Out of the 141 respondents who agreed to participate in this survey, 54 were male and 87 were female. The respondents' age ranged from 19 to 34 with the majority being 22 years old. Students from Semester 2 $(23.4 \%)$ and Semester $4(26.24 \%)$ were the biggest groups of students in this study. Questionnaire was administered to measure the students' perception on three aspects of the PBL sessions that include students' and facilitators' role in PBL, mode and scope of use of Internet in PBL by the students, and reasons for the use of Internet in PBL. A 5-point Likert scale (from "strongly disagree" to "strongly agree" with "somewhat agree" as mid-point) 
was used in the questionnaire. A pilot study was done to validate the internal consistency (Cronbach's coefficient alpha 0.78) of the items with 25 students. An initial pool of 45 questions was reduced to a 20-item questionnaire.

\section{Data Analysis}

Microsoft Excel and SPSS 18 were the main programmes used for analysing data after collection. The statistical test used was Kruskal-wallis Test. For this analysis, the question groups were merged according to the response from different semesters. Informed consent was obtained from all students who participated in the survey.

\section{RESULTS}

The results showed that $95.04 \%$ of the students knew about PBL and 58.8\% agreed that PBL process involved active learning. Table 1 shows that although there is an agreement towards the opinion that all students in the group should speak and participate actively in the discussion during the PBL session, there is difference in agreement about the opinion on how the facilitator should intervene in the process of PBL. Although PBL is a well-known process of self-directed learning, $26.9 \%$ of the students still thought that facilitators should teach during the PBL session (refer Table 1).
Majority of the students agreed that WiFi was the most common mode of use of Internet in the university. Personal laptop followed by the mobile phone was more common devices used. About $61 \%$ students disagreed that lack of time prevented them to use the Internet. Regarding duration of use of Internet, only $52.6 \%$ of the students agreed that they used Internet more than five hours in a day inside the university. Majority of the students did not agree that lack of time was a barrier to the use of Internet. Students searched Internet both during PBL Session 1 and PBL Session 2. A high percentage of students $(65.2 \%)$ agreed that they used Internet to search for new information during PBL Session 1. Regarding preparation for PBL Session 2, 58.2\% agreed that they used Internet. There is some difference in the students' perception about use of textbooks and use of Internet to prepare for the PBL Session $2(65.3 \%$ of the students agreed that they used textbooks [mean 3.73], and $59.6 \%$ of the students agreed that they used Internet [mean 3.76]) (refer Table 2). The perception analysis of students from earlier semesters (Semester 2 and Semester 4) showed that mean score was higher in agreement towards learning from textbooks.

Among several options (learning new knowledge, learning new skills, building strong foundation, building communication skills, sharing view points), most of the students $(81 \%)$ agreed that they used the Internet to learn new knowledge during the PBL. Regarding the most common

Table 1: The opinions of medical students regarding the students' and facilitators' role in PBL

\begin{tabular}{llccccccc}
\hline No. Question & $\begin{array}{c}\text { Strongly } \\
\text { agree } \\
(\%)\end{array}$ & $\begin{array}{c}\text { Agree } \\
(\%)\end{array}$ & $\begin{array}{c}\text { Somewhat } \\
\text { agree } \\
(\%)\end{array}$ & $\begin{array}{c}\text { Disagree } \\
(\%)\end{array}$ & $\begin{array}{c}\text { Strongly } \\
\text { disagree } \\
(\%)\end{array}$ & Mean & $P$ \\
\hline 1. & $\begin{array}{l}\text { All students should speak } \\
\text { during PBL }\end{array}$ & $79(56)$ & $29(20.6)$ & $19(13.5)$ & $13(9.2)$ & $1(0.7)$ & 4.5 & 0.48 \\
2. & $\begin{array}{l}\text { Facilitators should speak } \\
\text { only when some students' } \\
\text { points are wrong }\end{array}$ & $17(12)$ & $40(28.4)$ & $31(22)$ & $38(27)$ & $15(10.6)$ & 3.0 & 0.004 \\
3. & $\begin{array}{l}\text { Facilitators should actively } \\
\text { teach during PBL }\end{array}$ & $10(7.1)$ & $28(19.8)$ & $51(36.2)$ & $37(26.3)$ & $15(10.6)$ & 2.87 & 0.09 \\
\hline
\end{tabular}


Table 2: The opinions of medical students regarding the mode and scope of use of Internet in PBL

\begin{tabular}{|c|c|c|c|c|c|c|c|c|}
\hline No. & Question & $\begin{array}{l}\text { Strongly } \\
\text { agree } \\
(\%)\end{array}$ & $\begin{array}{c}\text { Agree } \\
(\%)\end{array}$ & $\begin{array}{l}\text { Somewhat } \\
\text { agree } \\
\text { (\%) }\end{array}$ & $\begin{array}{l}\text { Disagree } \\
\text { (\%) }\end{array}$ & $\begin{array}{l}\text { Strongly } \\
\text { disagree } \\
\text { (\%) }\end{array}$ & Mean & $P$ \\
\hline 1. & $\begin{array}{l}\text { Wi-Fi is the most } \\
\text { common mode of use of } \\
\text { Internet }\end{array}$ & $67(47.5)$ & $36(25.5)$ & $16(11.3)$ & $11(7.8)$ & $11(7.8)$ & 4.00 & 0.27 \\
\hline 2. & $\begin{array}{l}\text { Total time of use of } \\
\text { Internet exceeds five } \\
\text { hours/day }\end{array}$ & $46(32.6)$ & 29 (20.6) & $16(11.3)$ & 25 (17.7) & $25(17.7)$ & 3.00 & 0.12 \\
\hline 3. & $\begin{array}{l}\text { Lack of time is a barrier } \\
\text { to use of Internet }\end{array}$ & - & $55(39)$ & - & $86(61)$ & - & 1.61 & 0.11 \\
\hline 4. & $\begin{array}{l}\text { Internet is used for } \\
\text { search during PBL } \\
\text { Session } 1\end{array}$ & 37 (26.2) & $55(39)$ & $31(22)$ & $10(7.1)$ & $8(5.7)$ & 4.05 & 0.02 \\
\hline 5. & $\begin{array}{l}\text { Internet is used } \\
\text { for preparation of } \\
\text { presentation of PBL } \\
\text { Session } 2\end{array}$ & $32(22.7)$ & $50(35.5)$ & $38(26.9)$ & $11(7.8)$ & $10(7.1)$ & 3.89 & 0.09 \\
\hline 6. & $\begin{array}{l}\text { I use mostly textbooks } \\
\text { for my learning process } \\
\text { in PBL }\end{array}$ & $43(30.5)$ & $49(34.8)$ & $27(19.1)$ & $11(7.8)$ & $11(7.8)$ & 3.73 & 0.43 \\
\hline 7. & $\begin{array}{l}\text { I use mostly Internet } \\
\text { resources for my } \\
\text { learning process in PBL }\end{array}$ & $29(20.6)$ & $55(39)$ & $36(25.5)$ & $14(9.9)$ & $7(5.0)$ & 3.76 & 0.48 \\
\hline
\end{tabular}

practice for use of Internet in preparation for PBL Session 2, comparatively little percentage of students agreed that they searched online journals for the preparation. Similarly, fewer students searched Internet for epidemiological and psychosocial issues related to the PBL trigger. Percentage of students who agreed on searching for information on clinical sciences was higher $(52.5 \%)$ than those agreed on searching for information on basic sciences (28.4\%). Among the different search engines, Google (48.9\%) and PubMed (22.5\%) were the preferable choices followed by ClinicalKey $(19 \%)$. Students' perception about the searching for information on different disciplines of basic sciences during the PBL using Internet was analysed. Information on pathology was searched most (45.7\%), followed by anatomy and physiology $(22.2 \%)$. A smaller percentage $(13.6 \%)$ of students searched for information on public health, biochemistry and pharmacology. Majority of the students $(74.5 \%)$ agreed that the most common online search for information on clinical sciences was the management of disease process (refer Table 3).

\section{DISCUSSION}

In this study, the perception of the medical students towards the mode of use of Internet and common reasons for the use of Internet in PBL sessions was analysed. In addition, students' opinion towards the role of facilitator in PBL process was also analysed. The active role of the students during the PBL session was agreed upon by the students. The mean score of Likert scale on agreement of the students towards all students speaking and discussing during the PBL session was high. The perception of the students towards the role of the facilitator in the PBL session was not clear. While $40.4 \%$ of the students agreed that the facilitator should speak only when students' 
Table 3: The opinion of medical students regarding the common reasons and practices for use of Internet resources

\begin{tabular}{|c|c|c|c|c|c|c|}
\hline No. & Question & Option 1 & Option 2 & Option 3 & Option 4 & Option 5 \\
\hline 1. & $\begin{array}{l}\text { Most common } \\
\text { reason for use of } \\
\text { Internet resources }\end{array}$ & $\begin{array}{l}\text { Learn new } \\
\text { knowledge } \\
(81 \%)\end{array}$ & $\begin{array}{l}\text { Learn new skills } \\
(7.1 \%)\end{array}$ & $\begin{array}{l}\text { Build strong } \\
\text { foundation } \\
(3.5 \%)\end{array}$ & $\begin{array}{l}\text { Develop } \\
\text { communication } \\
\text { skills } \\
(3.5 \%)\end{array}$ & $\begin{array}{l}\text { Share view } \\
\text { points } \\
(4.9 \%)\end{array}$ \\
\hline 2. & $\begin{array}{l}\text { Most common } \\
\text { practice for use of } \\
\text { Internet during PBL }\end{array}$ & $\begin{array}{l}\text { Search for } \\
\text { information on } \\
\text { clinical sciences } \\
(52.5 \%)\end{array}$ & $\begin{array}{l}\text { Search for } \\
\text { information on } \\
\text { basic sciences } \\
(28.4 \%)\end{array}$ & $\begin{array}{l}\text { Read articles } \\
\text { from online } \\
\text { journals } \\
(7.8 \%)\end{array}$ & $\begin{array}{l}\text { Search for } \\
\text { general } \\
\text { information like } \\
\text { psychosocial } \\
\text { issues } \\
(4.3 \%)\end{array}$ & $\begin{array}{l}\text { Search for } \\
\text { epidemiology } \\
\text { of the disease } \\
(7 \%)\end{array}$ \\
\hline 3. & $\begin{array}{l}\text { Search engines } \\
\text { used }\end{array}$ & $\begin{array}{l}\text { Google } \\
(48.9 \%)\end{array}$ & $\begin{array}{l}\text { PubMed } \\
(22.5 \%)\end{array}$ & $\begin{array}{l}\text { Clinical Key } \\
(19 \%)\end{array}$ & $\begin{array}{l}\text { Medscape } \\
(7.4 \%)\end{array}$ & $\begin{array}{l}\text { Yahoo } \\
(2.2 \%)\end{array}$ \\
\hline 4. & $\begin{array}{l}\text { Discipline wise } \\
\text { search (basic } \\
\text { science) }\end{array}$ & $\begin{array}{l}\text { Anatomy, } \\
\text { Physiology } \\
(22.2 \%)\end{array}$ & $\begin{array}{l}\text { Biochemistry, } \\
\text { Pharmacology } \\
(13.6 \%)\end{array}$ & $\begin{array}{l}\text { Pathology } \\
(45.7 \%)\end{array}$ & $\begin{array}{l}\text { Microbiology } \\
(4.9 \%)\end{array}$ & $\begin{array}{l}\text { Public health } \\
(13.6 \%)\end{array}$ \\
\hline 5. & $\begin{array}{l}\text { Most common } \\
\text { search in clinical } \\
\text { science is on } \\
\text { management of } \\
\text { disease process }\end{array}$ & $\begin{array}{l}\text { Strongly agree } \\
(27 \%)\end{array}$ & $\begin{array}{l}\text { Agree } \\
(47.5 \%)\end{array}$ & $\begin{array}{l}\text { Somewhat } \\
\text { agree } \\
(18.4 \%)\end{array}$ & $\begin{array}{l}\text { Disagree } \\
(2.8 \%)\end{array}$ & $\begin{array}{l}\text { Strongly } \\
\text { disagree } \\
(4.3 \%)\end{array}$ \\
\hline
\end{tabular}

point of discussion was wrong, $26.9 \%$ of the students agreed that facilitator should actively teach. The availability of the Wi-Fi in the universities and the affordability of the personal devices were supported by the perception analysis. The use of Internet by the students during their learning process in the PBL Session 1 and PBL Session 2 was apparent in the perception analysis by the higher mean score of agreement in the Likert scale and only $12 \%$ to $14 \%$ of the students' disagreement to the use. Similar to the finding of the study, a previous study has found that introduction of webbased PBL scenario brought positive effects and made the PBL group more focused. Students' interaction with webbased platform did not adversely affect the discussion and there was no long-term negative effect on group dynamics (8). The observation of significant agreement towards the use of Internet to search for information during PBL Session 1, suggests the inquiry-based approach of the PBL. While going through the PBL trigger, some unknown concepts or key-points were identified by the students. As none from the group was able to discuss about the key- points, students searched Internet to get information about the key-points. About $81 \%$ of the students agreed that the most common reason for the use of Internet was to search for new information. An analysis comparing PBL curricula and traditional curricula found that medical students in PBL curricula performed better on tests of clinical knowledge than traditional medical students. Their performance in basic medical sciences knowledge was lower than similar performance in clinical knowledge (9). Regarding the most common practice for the use of Internet, higher percentage of students $(52.5 \%)$ agreed that they searched for information on clinical sciences. Regarding the primary search engine used to search for information, Google was preferred by most of the students followed by PubMed. The preference of the students about these two search engines was most likely due to successful opening of the URLs carrying the search results. Using information on breast cancer as a criterion, a study analysed search validity of search engines. Search validity is the measure of successful opening of the URL of search result. The validity of Google search 
results was $100 \%$ followed by Yahoo with validity of $92.5 \%$ (10). Most of the students agreed that pathology was searched, more commonly compared to the other basic medical science subjects. Learning from textbook, to prepare for PBL, was agreed upon by higher percentage of students from lower semesters compared to learning from the Internet.

\section{CONCLUSION}

The perception analysis of medical students from Malaysia showed that the students actively use Internet for searching for new information and learning during PBL sessions. However, the use of textbooks is an important mode for learning and preparing for PBL. The perception analysis also showed the lack of interest of the students towards the Internet search for online journals. Well-constructed PBL triggers and efficient facilitation can motivate the students towards in-depth inquiry-based learning. The future research can be directed towards establishing the relationship between the quality of PBL triggers and the use of journal articles by the students in the PBL session discussions. The medical schools have an important role in improving the quality of student discussion during the PBL and facilitate further the emerging interest among the students in self-learning using the Internet. The number of students from different semesters of medical programme who participated in this study was not similar. Comparatively a greater number of students was from Semester 2 and Semester 4. Unequal number of students from different semesters was a limitation of the study.

\section{ACKNOWLEDGEMENTS}

The authors acknowledge the support received from the Centre for Research and Development Taylor's University towards ethics clearance of the project.

\section{ETHICAL APPROVAL}

The present study was evaluated and approved by the Ethics committee in The Centre for Research and Development, Taylor's University, Malaysia.

\section{REFERENCES}

1. Preeti B, Ashish A, Shriram G. Problem based learning (PBL) - an effective approach to improve learning outcomes in medical teaching. J Clin Diagn Res. 2013;7(12):2896-7. https://doi.org/10.7860/ JCDR/2013/7339.3787

2. Wood DF. Problem based learning. BMJ. 2003;326(7384):328-30. https://doi.org/10. $1136 / \mathrm{bmj} .326 .7384 .328$

3. Yew EHJ, Goh K. Problem-based learning: an overview of its process and impact on learning. Health Prof Educ. 2016;2(2):75-9. https://doi.org/10.1016/j.hpe.2016.01.004

4. Norman GR, Schmidt HG. The psychological basis of problem-based learning: a review of the evidence. Acad Med. 1992;67(9):557-65. https://doi.org/10. 1097/00001888-199209000-00002

5. Olowa OW. An assessment of internet uses, practices, and barriers for professional development by agricultural science teachers in Lagos state. Edu Res Int. 2012;1-7. https://doi.org/10.1155/2012/503264

6. Amoako-Sakyi D, Amonoo-Kuofi $\mathrm{H}$. Problem-based learning in resource-poor settings: lessons from a medical school in Ghana. BMC Med Edu. 2015;15:221. https://doi.org/10.1186/s12909-015-0501-4

7. Wutoh R, Boren SA, Balas EA. eLearning: a review of Internet-based continuing medical education. J Contin Educ Health Prof. 2004;24(1):20-30. 
8. Persson AC, Fyrenius A, Bergdahl B. Perspectives on using multimedia scenarios in a PBL medical curriculum. Med Teach. 2010;32(9):766-72. https://doi.org/10.3109/ 01421591003688381

9. Vernon DT, Blake RL. Does problem-based learning work? A meta-analysis of evaluative research. Acad Med. 1993;68(7):550-63. https://doi.org/10.1097/00001888-19930700000015
10. Wang L, Wang J, Wang M, Li Y, Liang Y, $\mathrm{Xu} \mathrm{D}$. Using Internet search engines to obtain medical information: a comparative study. J Med Internet Res. 2012;14(3):e74. https://doi.org/10.2196/jmir.1943 